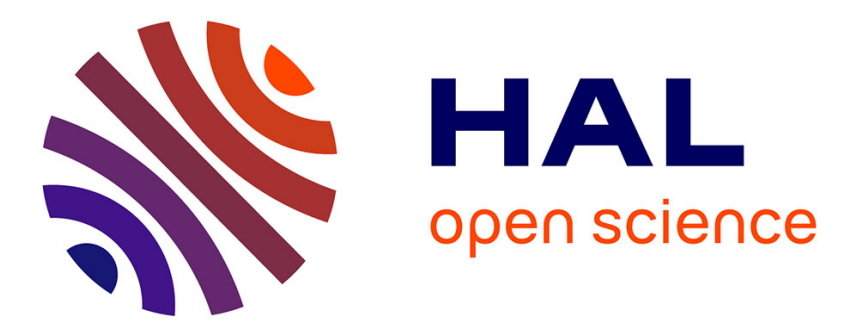

\title{
The EU and Its Neighbourhoods: A Textual Analysis on Key Documents of the European Neighbourhood Policy
}

Laurent Beauguitte, Yann Pierrick Gérald Richard, France Guérin-Pace

\section{To cite this version:}

Laurent Beauguitte, Yann Pierrick Gérald Richard, France Guérin-Pace. The EU and Its Neighbourhoods: A Textual Analysis on Key Documents of the European Neighbourhood Policy. Geopolitics, 2015, 20 (4), p. 853-879. 10.1080/14650045.2015.1075512 . halshs-01213789

\section{HAL Id: halshs-01213789 \\ https://shs.hal.science/halshs-01213789}

Submitted on 9 Oct 2015

HAL is a multi-disciplinary open access archive for the deposit and dissemination of scientific research documents, whether they are published or not. The documents may come from teaching and research institutions in France or abroad, or from public or private research centers.
L'archive ouverte pluridisciplinaire HAL, est destinée au dépôt et à la diffusion de documents scientifiques de niveau recherche, publiés ou non, émanant des établissements d'enseignement et de recherche français ou étrangers, des laboratoires publics ou privés. 


\title{
The EU and Its Neighbourhoods: A Textual Analysis on Key Documents of the European Neighbourhood Policy
}

\author{
Laurent Beauguitte (UMR IDEES) \\ Yann Richard (Université Paris I Panthéon Sorbonne) \\ France Guérin-Pace (INED) \\ Geopolitics, September 2015 \\ DOI: $10.1080 / 14650045.2015 .1075512$
}

\begin{abstract}
Over the last twenty years, European Union (EU) actorness at both regional and global scales, has become a fruitful topic of analysis in the field of political science, and more specifically in international relations and political geography. Critical geopolitics dedicated many substantive papers on EU discourses and representations. Our paper aims at providing a complementary way to study texts issued by the EU and to question EU actorness by adopting an approach based on textual analysis. The corpus examined includes the seven communications on the European Neighbourhood Policy (ENP) issued between 2003 and 2013. These communications provide essential information regarding relations between the EU and its immediate neighbours. The textual analysis allows several relevant characteristics of discourses to be highlighted: stability and changes, actors, spaces and scales mentioned. The outcomes of the analysis confirm previous research on the subject: The ENP appears as a bilateral state-centric policy, missing global scale, and neglecting the role of regional powers like Turkey or Russia.
\end{abstract}

\section{Introduction}

The European Neighbourhood Policy (ENP) has been implemented since 2004 with the objective of avoiding the emergence of new dividing lines between the enlarged European Union (EU) and neighbouring States ${ }^{1}$. It also

\footnotetext{
${ }^{1}$ The countries eligible to the ENP are: Morocco, Algeria, Tunisia, Libya, Egypt, Israel, Jordan, Lebanon, Syria, Azerbaijan, Armenia, Georgia, Moldova, Ukraine, Belarus.
} 
aims at strengthening the prosperity, stability and ensuring security of all ${ }^{2}$. The ENP has been scrutinised in a large number of publications mainly written by specialists in international relations, lawyers and, more recently, political geographers. Their research has addressed numerous aspects, in particular: the basic principles of the ENP, its instruments ${ }^{3}$, its developments and its effectiveness from local and regional scales (especially crossborder or inter-governmental cooperation with neighbouring countries $\left.{ }^{4}\right)$ to the macroregional one. This research often focuses on the exclusive and ambiguous nature of the ENP. Some authors stress the asymmetrical nature of the European neighbourhood policy, which puts the interests of the European Union ahead of those of its neighbouring countries, and partly explains its failure to achieve its stated objectives.

A significant part of this research seeks to interpret the content of the neighbourhood policy. Affirming the EU's spatial and political identity might indeed be an indirect way of telling the neighbours that it will permanently remain closed. If so, by defining the ENP, the EU defines itself as distinct from an irreducible 'Other' ${ }^{5}$ consisting of neighbours who are not European enough to eventually join the EU. Given the strong conditionalities that structure the $\mathrm{ENP}^{6}$, this policy could have been considered a policy instrument for stabilising the regional environment of the EU, by encouraging neighbouring countries to adopt predictable behaviours and standards acceptable to the European Union. The EU is in this case presented as a normative power ${ }^{7}$. The ENP enables it to extend the geographical scope of its foreign policy and disseminate its model and preferences over a regional area well beyond its official borders, sketching out what some observers have seen as a form of imperialism ${ }^{8}$. Paradoxically, this Europeanisation of 'the neighbourhood', even if uneven, helps to blur the line between those inside and those outside the EU, and undermines the idea that the EU is a geo-

\footnotetext{
${ }^{2}$ European Union's website: http://europa.eu/rapid/press-release_MEMO-13236 en.htm, accessed 19 June 2014.

${ }^{3}$ J. Kelley, New Wine in Old Wineskins: Promoting Political Reforms Through the New European Neighbourhood Policy, Journal of Common Market Studies 44/21 (2006) pp. 29-55; R. G. Whitman and S. Wolf, The EU as a Conflict Manager? The Case of Georgia and its Implications, International Affairs 86/1 (2010) pp. 87-107.

${ }^{4}$ N. Gaubert and Y. Richard, European Cohesion Policy and Territorial Cooperation with Neighbouring Countries: Towards Deeper Coordination?, European Journal for Spatial Development (2010), available at http://www.nordregio.se/ejsd/refereed41.pdf.

${ }^{5} \mathrm{~J}$. Scott, The EU and Wider Europe: Towards an Alternative Geopolitics of RegionalCooperation?, Geopolitics 10/3 (2005) pp. 429-454; V. Kostadinova, The Commission, ENP and Construction of Borders, Geopolitics 14/2 (2009) pp. 235-255.

${ }^{6}$ J. Kelley, Ethnic Politics in Europe: The Power of Norms and Incentives (Princeton: Princeton University Press 2004); Kelley, New Wine (note 3).

${ }^{7}$ I. Manners, Normative Power Europe: A Contradiction in Terms?, Journal of Common Market Studies 40/2 (2002) pp. 235-258; Z. Laïdi, La norme sans la force. L'énigme de la puissance européenne (Paris: Presses de Sciences Po 2005).

${ }^{8}$ F. Boedeltje and H. van Houtum, Questioning the EU's Neighbourhood Geo-Politics: Introduction to a Special Section, Geopolitics 16/1 (2011) pp. 121-129.
} 
graphically well-defined entity ${ }^{9} .9$ The European Neighbourhood Policy can be regarded as an instrument of influence, a lever for Europeanisation. In other words, the ENP is a means to export the European model to neighbouring countries ${ }^{10}$ and to act as a soft power to secure its borders ${ }^{11}$.

Starting from the existing literature we accept as a postulate that the ENP is used by the European Union as a lever to boost its influence in its regional environment in order to ensure stability and security beyond its borders. This postulate is based on the idea that the European Union sees itself and seeks to be considered by its partners, especially the neighbouring countries, as a major player in international relations. This idea is still widely debated ${ }^{12}$ but increasingly accepted by researchers in the field of International Relations. Some of them have taken a further step and argue that the EU is a new type of power ${ }^{13}$. The policy has also given rise to

${ }^{9}$ T. Christiansen, F. Petito, and B. Tonra, Fuzzy Politics around Fuzzy Borders: The European Union's Near Abroad, Cooperation and Conflict 35/4 (2000) pp. 389-415; V. Tsankova, Les mécanismes internes de l'intégration européenne et le défi de l'élargissement vers l'Europe centrale et orientale, in D. Van Eeuwen and M. Duquette (eds.), Les nouveaux espaces de l'intégration. Les Amériques et l'Union européenne (Paris: Karthala 2005) pp. 215-252; D. Van Eeuwen, Préface, in F. Taglioni and J.M. Théodat (eds.), Coopération et intégration. Perspective panaméricaine (Paris: L'Harmattan 2007) pp. 9-13.

${ }^{10}$ L. Bialasiewicz, Off-Shoring and Out-Sourcing the Borders of Europe: Libya and EU Border Work in the Mediterranean, Geopolitics 17/4 (2012) pp. 843-866.

${ }^{11}$ E. Tulmets, Policy Adaptation from Enlargement in the European Neighbourhood Policy: A Way to Improve EU's External Capabilities?, Politique européenne 22/2 (2007) pp. 55-80.

${ }^{12}$ C. Hill, The Capability-Expectations Gap, or Conceptualising Europe's International Role, Journal of Common Market Studies 31/1 (1993) pp. 305-328; C. Bretherton and J. Vogler, The European Union as a Global Actor (London: Routledge 1999); D. Helly and F. Petiteville, L'Union européenne, acteur international (Paris: L'Harmattan 2005); F. Petiteville, La politique internationale de l'Union européenne (Paris: Presses de Sciences Po 2006); S. Lavenex and F. Merand, Nouveaux enjeux sécuritaires et gouvernance externe de l'Union européenne, Politique européenne 22 (2007) pp. 5-14; C. Franck, L'Union européenne dans les relations internationales. Genèse et développement d'un acteur global, in C. Franck and G. Duchenne (eds.), L'action extérieure de l'Union européenne. Rôle global, dimension matérielle, aspects juridiques, valeurs. Actes de la XIe Chaire AGC (ex-Glaverbel) d'études européennes (Brussels and Leuven: Bruylant Academia 2008) pp. 25-74; Y. Richard and G. Van Hamme, L'Union européenne, un acteur des relations internationales. Etude géographique de l'actorness européenne, L'Espace Géographique 1 (2013) pp. 15-31.

${ }^{13} \mathrm{~F}$. Duchêne, The European Community and the Uncertainties of Interdependence, in M. Kohnstamm and W. Hager (eds.), A Nation Writ Large? Foreign-Policy Problems before the European Community (London: Macmillan 1973) pp. 1-22; Manners, Normative Power: Contradiction? (note 7); I. Manners, Normative Power Europe: Beyond the Crossroads, Journal of European Public Policy 13/2 (2006) pp. 182-199; Laïdi (note 7); M. Pace, The Construction of EU Normative Power, Journal of Common Market Studies 45/5 (2005) pp. 1041-1064; S. Rynning, Return of the Jedi: Realism and the Study of the European Union, Politique européenne 3/17 (2005) pp. 10-33; G. Balducci, Inside Normative Power Europe: Actors and Processes in the European Promotion of Human Rights in China, EU Diplomacy Papers, 8 (Bruges: Collège d'Europe 2008), available at http://aei.pitt.edu/9606/1/EDP_8_2008.Balducci.pdf. 
an abundant literature on the concept of 'actorness' ${ }^{14}$, that is the quality of being an actor in international relations. Sjöstedt ${ }^{15}$ and Smith $^{16}$ define actorness as the ability to act deliberately and actively in relation to others in the international system. Sjöstedt links actorness to the notion of ability, that is: the capability to respond effectively to external expectations and opportunities. This assumes the existence of shared values, the legitimacy of the decision-making and priority-setting process in foreign policy, and the ability to identify, design and implement policy and to use the whole range of international relations instruments. In this article, we will not dwell on the actual neighbourhood policy itself, on its perception in countries eligible to participate, or on observed or expected effects. Instead we examine its thematic content as it is stated explicitly in key policy documents (part 1.2), in order to understand what are the essential concerns of the EU regarding its neighbourhood.

Our purpose is to contribute to the debate on EU actorness at international level by carrying out a close lexical analysis of the seven official documents that constitute the framework for the European Neighbourhood Policy. Our central hypothesis is that the EU, as an actor in international relations, is able to formulate a specific and innovative discourse concerning what it designates as its neighbourhood. Analysing this discourse enable us to evaluate the degree of actorness of the European Union. We use statistical text analysis ${ }^{17}$

1. to reveal the key points of the ENP framework texts by analysing their vocabulary, the lexical worlds they refer to and their structure;

2. to observe the impact of events within and outside the EU on the way it expressed itself about its neighbourhood countries from 2003 to 2013;

3. to contribute to the debate on the role of the EU in international relations by comparing our results with those obtained in critical geopolitics and constructivist approaches.

In Part 1, we review the state of the art and we present in detail the corpus of analysed texts and the tools and methods used. We show how a close lexical analysis complements critical discourse analysis and can be applied to the critical geopolitical study of the European Union. In part 2,

\footnotetext{
${ }^{14}$ J. Caporaso and J. Jupille, States, Agency and Rules: The European Union in Global Environmental Politics, in C. Rhodes (ed.), The European Union in the World Community (Boulder, CO: Lynne Rienner 1998) pp. 213-229; Bretherton and Vogler (note 12).

${ }^{15}$ G. Sjöstedt, The External Role of the European Community (Westmead: Saxon House 1977).

${ }^{16}$ M. Smith, European Foreign and Security Policy. The Institutionalization of Cooperation (Cambridge: Cambridge UP 2003).

${ }^{17}$ L. Lebart and A. Salem, Analyse statistiques des données textuelles (Paris: Dunod 1988).
} 
we present the results of the text analysis of the key policy documents, highlighting their geographical dimension, with the aim of discovering how the European Union perceives its neighbourhood. The geographical dimension addressed in the paper pertains more specifically to the spaces mentioned and the scales (from the local to the global) referred to in the documents. We then return to our hypothesis about EU actorness and show that the European discourse reveals certain weaknesses in the neighbourhood policy, confirming weaknesses that have already been highlighted in previous studies using different approaches.

\section{Actor and Actorness: Approaches related to the European Union and Discourse Analysis}

In this section, we first explain the criteria of actorness presented by various scholars in the academic literature on international relations. Second, we explain which criteria of actorness, applied to the European Union and its relations with its neighbourhood, are studied in this paper. Third, we present the corpus of official documents (the seven strategic Communications of the European Commission and later with the High Representative for Foreign Affairs on the European Neighbourhood Policy) on which this study is based and we explain why this corpus is particularly relevant. Last, we present our textual analysis method and highlight its added value, compared to the methods usually deployed in the existing geopolitical literature on the ENP.

\subsection{Criteria for the European Union's 'Actorness'}

Since the 1970s, many scholars have debated the nature of the European Union, in particular its status as an actor in international relations ${ }^{18}$. An 'actor' is an individual or collective entity that can elaborate a strategy of its own and acts autonomously to achieve its objectives ${ }^{19}$. From this perspective, the ENP can be considered as a way for the EU to define and promote a political strategy that involves its neighbours. The concept of actor, which was first designed for states within a realist approach to international relations (Realpolitik), has since been extended to other types of entities engaged in international or cross-border activities (international organisations, non-state bodies such as NGOs, transnational corporations,

\footnotetext{
${ }^{18}$ S. Hoffmann and R. O. Keohane (eds.), The New European Community: Decision Making and Institutional Change (Boulder: CO, Westview Press 1991); A. Moravcik, Preferences and Power in the European Community: A Liberal Intergovernmentalist Approach, Journal of Common Market Studies 31 (1991) pp. 473-524; C. Lequesne, La Commission européenne entre autonomie et dépendance, Revue française de science politique 46/3 (1996) pp. 389-408.

${ }^{19}$ M. Crozier and E. Friedberg, L'acteur et le système (Paris: Seuil 1992).
} 
etc. $\left.{ }^{20}\right)$.

Using a realist approach, some specialists in international relations keep questioning the status of the EU as an actor with an interesting argument: it is neither a state nor a constituted political entity, and cannot therefore act rationally ${ }^{21}$. Consequently, it cannot be a fully fledged actor in international relations ${ }^{22}$. Within this approach, the very concept of actor can in no way be applied to the $\mathrm{EU}^{23}$. As early as 1977, Sjöstedt signalled this problem by stating that the European Community (the predecessor of the EU) was an 'incomplete' actor unable to combine the interests and preferences of Member States in order to undertake an autonomous external action ${ }^{24}$. Recent studies have sought to show that the EU could be considered as an actor, by pointing out the fact that its uncertain status as a political entity has been clarified and better defined in the Maastricht Treaty (1992) and Lisbon Treaty (2007) ${ }^{25}$ with the establishment of the High Representative for the EU Foreign Affairs and the European External Action Service (EEAS). For our analysis, the non-mandatory nature of the ENP seems to indicate that the actorness of the Member States could limit the actorness of the EU.

These debates have been to some extent superseded by recent studies on the notions of actor and actorness. More specifically, Bretherton and Vogler $^{26}$ propose a new definition of the concept based on three criteria:

1. opportunity, the context in which the activity of the EU is decided, suggesting the fact that none of actors involved is completely autonomous;

2. presence, the ability of the actor to exercise an influence beyond its borders and affect the behaviour of its partners so that they adopt behaviours and preferences deemed acceptable;

3. capability, the ability or inability of the EU to undertake actions is closely determined by the internal context within the EU.

In the same vein Caporaso and Jupille ${ }^{27}$ suggest calling the EU a 'collective actor'. To measure degrees of actorness, they distinguish between four

\footnotetext{
${ }^{20} \mathrm{M}$. Merle, Les acteurs dans les relations internationales (Paris: Economica 1986).

${ }^{21}$ Lavenex and Merand (note 12).

${ }^{22}$ B. Rosamond, Conceptualizing the EU Model of Governance in World Politics, European Foreign Affairs Review 10/4 (2005) pp. 463-478; H. Hveem, Explaining the Regional Phenomenon in an Era of Globalization, in R. Stubbs and G. Underhill (eds.), Political Economy and the Changing Global Order (Oxford: Oxford University Press 2000) pp. $70-81$.

${ }^{23}$ T. Diez, Constructing the Self and Changing Others: Reconsidering Normative Power Europe, Millennium 33/3 (2005) pp. 613-636; H. Sjursen, The EU as a Normative Power: How Can This Be?, Journal of European Public Policy 13/2 (2006) pp. 235-251.

${ }^{24}$ Caporaso and Jupille (note 14); Bretherton and Vogler (note 12).

${ }^{25}$ Bretherton and Vogler (note 12); Helly and Petiteville (note 12); Petiteville, La politique internationale (note 12); Franck (note 12).

${ }^{26}$ Bretherton and Vogler (note 12).

${ }^{27}$ Caporaso and Jupille (note 14).
} 
dimensions of actorness:

1. cohesion, the ability of an actor to formulate and articulate consistent social and political preferences;

2. authority, the possibility of acting legally;

3. autonomy, the ability to act relatively independently, relying on the work done on the dialectical links between agent and structure ${ }^{28}$;

4. recognition, whether other actors agree to interact with the EU, for example, the way the EU is perceived by third parties ${ }^{29}$.

More recently, others have proposed the concept of a 'European system of external action'30. These various developments support the idea that the EU is indeed an actor (of some kind) in international relations ${ }^{31}$. In addition, a number of authors have examined the relationship between the status as an actor and effectiveness ${ }^{32}$, raising the question of the "capability expectation gap' between the stated objectives of the EU and the actual achievements ${ }^{33}$ - but this crucial aspect of EU actorness will remain beyond the scope of this paper, as we focus on stated policy objectives.

Building on the work already undertaken by Jupille and Caporaso and by Bretherton and Vogler, we propose to examine two criteria defining the actorness of the European Union by analysing the strategic communications

\footnotetext{
${ }^{28}$ A. Wendt, The Agent Structure Problem in International Relations Theory, International Organisation $41 / 3$ (1987) pp. 335-370.

${ }^{29}$ S. Lucarelli and L. Fioramonti, External Perceptions of the European Union as a Global Actor (London: Routledge 2010).

${ }^{30} \mathrm{D}$. Helly, Les modes d'action extérieure de l'Union européenne dans le Caucase du Sud, Revue française de science politique 55/2 (2005) pp. 243-268.

${ }^{31} \mathrm{~F}$. Petiteville, L'Union européenne, acteur international global ? Un agenda de recherche, La Revue internationale et stratégique 47 (2002) pp. 145-157; M. Smith, European foreign and Security Policy. The Institutionalization of Cooperation (Cambridge: Cambridge UP 2003); Helly and Petiteville (note 12).

${ }^{32}$ K. V. Laatikainen, Norden's Eclipse: The Impact of the European Union's Common Foreign and Security Policy on the Nordic Group at the United Nations, Cooperation and Conflict 38/4 (2003) pp. 409-441; K. E. Smith, Speaking With One Voice? European Union Co-ordination on Human Rights Issues at the United Nations, Journal of Common Market Studies 44/1 (2006) pp. 113-137; Bretherton and Vogler (note 12); R. H. Ginsberg, Conceptualizing the European Union as an International Actor, Journal of Common Market Studies 37/3 (1999) pp. 429-454; Hill, The Capability-Expectations Gap (note 12); C. Hill, Closing the Capability-Expectations Gap?, in J. Peterson and H. Sjursen (eds.), A Common Foreign Policy for Europe? Competing Visions of the CFSP (London: Routledge 1998).

${ }^{33}$ Hill, The Capability-Expectations Gap (note 12); S. Panebianco, Promoting Human Rights and Democracy in European Union Relations with Russia and China, in S. Lucarelli and I. Manners (eds.), Values and Principles in European Union Foreign Policy (London: Routledge (2006); O. Elgström and M. Smith (eds.), The European Union's Role in International Politics: Concepts and Analysis (London: Routledge 2006); Balducci (note 13).
} 
establishing the ENP released by the European institutions since 2003. The study will be focused mainly on cohesion (i.e., the capacity to formulate consistent preferences) and autonomy (i.e., the ability to act relatively independently). These two criteria have been selected because they can be assessed in a textual analysis of EU documents. Testing authority and recognition would entail an assessment of the viewpoints of external actors and of an assessment of the EU decision-making process and falls beyond the scope of this article.

\subsection{Critical Analyses of European Union Discourse and 'Ac- torness'}

Being an actor means being able to formulate a consistent discourse covering a wide range of specific topics. The notion of cohesion may be interpreted in various ways: it pertains first the ability to structure a discourse as well as to highlight its basic principles and priorities so that they are communicated effectively to partners; but also to the ability to formulate priorities that are consistent with each other; and to the ability to maintain principles and priorities over time. For example, an excessive volatility in the discourse would undermine that discourse and the EU would consequently lose credibility on the international stage. We then propose to reveal the relationship between variations in the European discourse and the evolutions of the external context. For its ENP the EU needs to find a balance between the need to be consistent and the need to react to changes: neglecting entirely the context would reduce the ability of the actor to act and would make its decisions ineffective as they are not connected to its immediate environment; but being entirely reactive to contextual changes would reduce the actor's autonomy to zero because its basic principles and priorities would become increasingly blurred.

To address EU actorness, critical discourse analysis ${ }^{34}$ is particularly relevant because it 'scrutinizes visible and opaque structural relationships of dominance, discrimination, power and control that occur in discourse, aiming at the critical exploration of social structuring revealed in the use of language ${ }^{35}$. It aims to 'investigate how practices, events and texts arise out of and are ideologically shaped by relations of power and struggles over power' and 'explore... the opacity of these relationships between discourse

\footnotetext{
${ }^{34}$ T. A. van Dijk, Principles of Critical Discourse Analysis, Discourse and Society 4/2 (1993) pp. 249-283; S. B. Rasmussen, Discourse Analysis of EU Public Diplomacy: Messages and Practices, Discussion Papers in Diplomacy (The Hague: Netherlands Institute of International Relations 'Clingendael' 2009) pp. 1-41; V. Ferati, Critical Discourse Analysis. (De-)Constructing EULEX Discourse (Prishtina: Kosovar Centre for Security Studies 2012).

${ }^{35}$ N. Fairclough, Critical Discourse Analysis and the Commodification of Public Discourse, Discourse and Society 4/2 (1993) pp. 133-168.
} 
and society ${ }^{36}$.

Behind this approach there is the idea that language, and therefore discourse, is an instrument of power and domination ${ }^{37}$. Our analysis does have a critical dimension inasmuch as it involves distancing ourselves from the statements made by institutions (the European Commission and the European External Action Service) and starts from the postulate that the analysed discourses are not limited to the unique purpose of providing an objective description of reality. Text analysis is used to reveal power relationships, discriminatory prejudices, and representations that are not necessarily explicit.

Using the postulates of critical discourse analysis, critical geopolitics aims to reveal the 'hidden' political meaning of geopolitical knowledge and consequent discourse. It assumes that geopolitical discourses do not tell an absolute truth and that actors are seeking to establish their own truth by formulating discourses ${ }^{38}$. The production of geopolitical knowledge is thus presented as a political act, because these discourses are not distanced and neutral description of an objective reality. In formulating discourse, the aim of these actors is also - if not primarily - to justify their own power.

Critical geopolitics has often been applied to relations between the EU and neighbouring countries. Jones and Clark examine what they call the discourses of Europeanisation and show how the production of discourse enables the European Union to justify the implementation of the ENP and the possible establishment of asymmetrical power relationships with the neighbourhood countries ${ }^{39}$. In our study, analysing the position of actors within sentences could be a first assessment of this asymmetrical relation: for example, if EU is always the subject of the verb, and neighbouring countries are always the object, it clearly indicates who is active and dominant in the relation.

Kratochvil shows how the EU seeks to construct an identity as an actor in its relations with neighbouring countries. While examining texts relating to the neighbourhood policy, he shows how it is inconsistent as the discourse swings between two contradictory positions in presenting the EU either as a power centre dominating its neighbourhood or as an equal among equals, using the idea of joint ownership ${ }^{40}$. This type of contradiction can also be

\footnotetext{
${ }^{36}$ Ibid.

${ }^{37} \mathrm{P}$. Bourdieu, Ce que parler veut dire : l'économie des échanges linguistiques (Paris: Fayard 1982).

${ }^{38}$ G. Ó Tuathail, Critical Geopolitics. The Politics of Writing Global Space (Minneapolis: University of Minnesota 1996); G. Ó Tuathail and P. Agnew, Geopolitics and Discourse. Practical Geopolitical Reasoning in American Foreign Policy, Political Geography Quarterly 11 (1992) pp. 190-204.

${ }^{39}$ A. Jones and A. Clark, Europeanisation and Discourse Building: The European Commission, European Narratives and European Neighbourhood Policy, Geopolitics 13/3 (2008) pp. 545-571.

${ }^{40}$ P. Kratochvil, Discursive Constructions of the EU's Identity in the Neighbourhood: An Equal Among Equals or the Power Centre?, European Political Economy Review 9
} 
observed in the EU ambiguous discourse about its external borders ${ }^{41}$, mixing both inclusive and exclusive representations ('soft' and 'hard' borders). In the same vein, Delcour and Tumets ${ }^{42}$ point out the importance of the security and defence issues in European discourse. They also show that the EU makes a clear distinction between neighbouring countries and candidate countries. In our study, an examination of the 'lexical worlds' associated with different countries could provide insights in those differences: 'hard' borders are likely to be characterised with a single lexical world while 'soft' ones present a greater variation.

Last, Boedeltje examines how the EU uses the ENP to export its values beyond its external borders.He analyses the EU geopolitical vision concerning its external borders and how the EU attempts to construct an enlarged neighbourhood ${ }^{43}, 43$ repeating a theme covered by other authors ${ }^{44}$. Reynaert shows that the European Commission promotes a certain type of social order in the Mediterranean, with a form of good governance based on the free market, freedom, democracy, the rule of law and human rights, compared to countries considered to be poorly governed ${ }^{45}$. Boedeltje and Van Houtum, similarly, show that ENP texts construct the image of neighbours as inferior to the EU, but potentially able to rise above that status if they comply with the European model. Their analysis of a series of policy texts shows that the EU maintains a neo-colonial relationship with its neighbours by bringing them to apply a predefined model presented as superior ${ }^{46}$. In our study, the analysis of lexical worlds and co-occurrences could provide additional insights on these aspects of ENP.

These approaches have been fruitful and share common features. They read in a linear fashion a set of documents and seek to find elements to support basic intuitions of critical geopolitics as formulated by Agnew, Ó Tuathail and Dalby ${ }^{47}$. They look for the implicit or explicit expression of power relationships in the texts. However the methodologies they are using

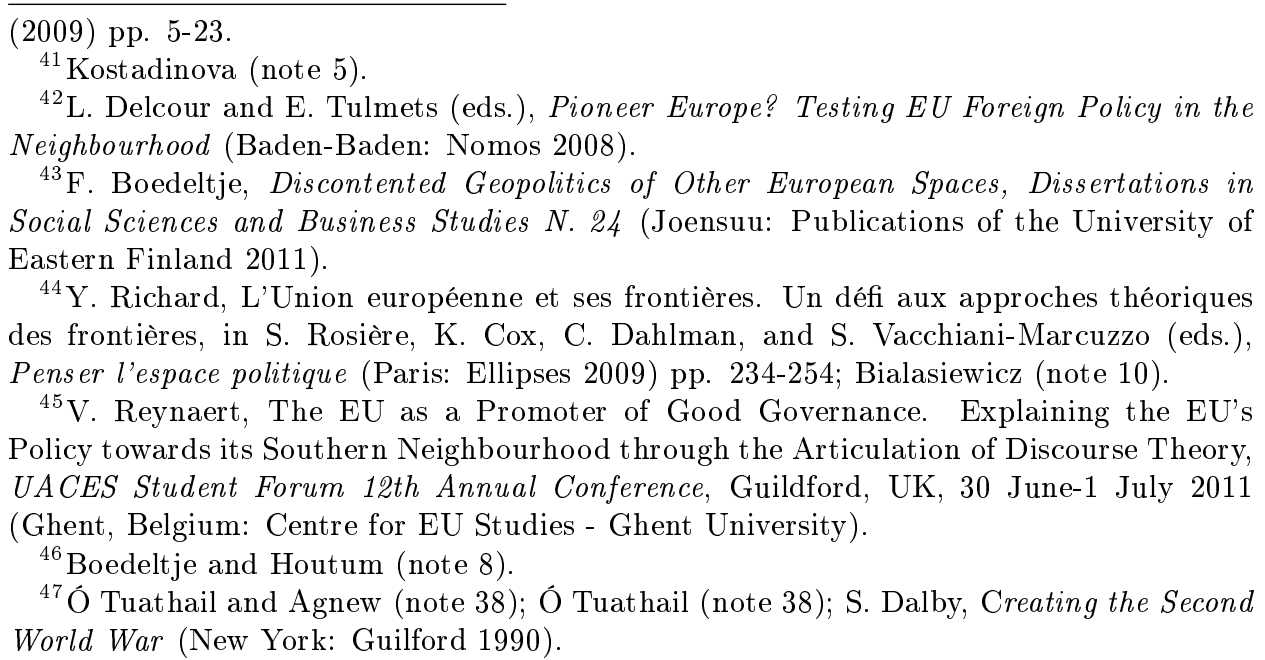


are not clearly explained. These analyses provide interesting results, but the variety of methods used and their sometimes implicit nature make an evaluation of the findings and comparisons between studies difficult. The corpuses of documents used by the authors are generally heterogeneous and not clearly defined. In this paper, we partially respond to this weakness by proposing a precise methodology to select and to analyse the corpus. Moreover, we believe that statistical text analysis applied to a highly homogeneous corpus of texts will complement the available research by confirming previous results and revealing or highlighting aspects that might be missed in a linear reading. It also allow us to quantify more precisely intuitions and findings presented in existing studies.

\subsection{A Homogeneous and Politically Significant Corpus}

The corpus reviewed in this article consists of seven official documents published between 2003 and 2013. On the basis of policy suggestions from the European Council and European Parliament, the Commission responds with formal proposals for new policy actions. These communications are not legislative texts to be implemented in national legislations but proposals for policy actions. They must not be confused with 'explanatory communications and proposals of legal acts', that enable the law-making institutions to adopt common policies, European legislation and programmes following an initiative from the Commission.

The Commission's communications have considerable importance for the operation of the European Union because they contain proposals for policy action. The seven framework communications in our corpus present the arguments, principles and objectives of the neighbourhood policy (ENP). They provide the framework within which the ENP is subsequently formulated by the competent institutions, then implemented and in some cases modified. The European Commission and later the European External Action Service (EEAS), which has headed the diplomatic action of the EU since 2010, published them successively. This diplomatic body set up by the Lisbon Treaty is independent of the European Commission but its actions must be consistent with action of other European institutions. However, it must be noted that the position and actions on ENP are not legally binding for the Member States but they embody a political commitment to join actions in the field of foreign policy.

Taken together these seven communications allow us to have a broad overview of the stated arguments, principles and objectives of the EU neighbourhood policy and their change over time. Covering a period of ten years adds a significant value as it brings an understanding of the internal context of the European Union and the impacts of successive enlargements (2004, 2007, 2013), the ratification of the Lisbon Treaty and the financial and economic crisis which caused the EU to modify rules of governance. The 
Box 1: Corpus studied (chronological order)

Wider Europe - Neighbourhood: A New Framework for Relations with our Eastern and Southern Neighbours, Brussels, 11 March 2003, Communication from the Commission to the Council and the European Parliament European Neighbourhood Policy, Brussels, 12 May 2004, Communication from the Commission, Strategy Paper

Communication from the Commission to the Council and the European Parliament, on strengthening the European Neighbourhood Policy, Brussels, 4 Dec. 2006

A Strong European Neighbourhood Policy, Brussels, 5 Dec. 2007, Communication from the Commission

A New Response to a Changing Neighbourhood. A review of European Neighbourhood Policy, Brussels, 25 May 2011, Joint Communication by the High Representative of The Union For Foreign Affairs And Security Policy and the European Commission

Delivering on a new European Neighbourhood Policy, Brussels, 15 May 2012, Joint Communication to the European Parliament, the Council, the European Economic and Social Committee and the Committee of the Regions

European Neighbourhood Policy: Working towards a Stronger Partnership, Brussels, 20 March. 2013, Joint Communication to the European Parliament, the Council, the European Economic and Social Committee and the Committee of the Regions

Lisbon Treaty allowed the EU to widen its competencies and favoured enhanced cooperation between Member States when it comes to external relations, defence and security issues. This impacted the ENP since these issues were gradually integrated in the action plans and association agendas defined jointly by the EU and its partner countries. The external context also changed: several conflicts erupted in the Southern and Eastern neighbourhood countries of the EU, the revival of Russia continued, and the relations with Turkey were going up and down. They have been drafted by several services but they have the same status and the advantage of addressing the same purpose over a relatively long period ${ }^{48}$. Even though the seven framework communications are not legislative binding acts, they are still important

\footnotetext{
${ }^{48}$ The first communication was written by a 'Wider Europe task force' set up within DG Enlargement in 2001. In 2004, the task force was transferred to DG Relex, but its membership remained relatively stable. In 2011, the group devising the ENP was finally transferred to the European External Action Service, with members of DG Relex, but its way of working remained the same. The ENP framework communications have always been written collegially by senior European officials and the Member States do not intervene in their drafting.
} 
policy documents reflecting the major role that the European Commission (and the EEAS since 2010) in foreign policy ${ }^{49}$, often more important than the statements of the European Council of Ministers ${ }^{50}$.

To preserve corpus homogeneity, we chose deliberately to exclude from our analysis the reports on the implementation of the neighbourhood policy. Despite their importance, these regular publications issued by the European Commission and later the EEAS have another function, compared to our the selected documents. They report on progress of and identify obstacles to the implementation of the ENP and contain neither policy suggestions nor actual proposals. These documents mainly focus on the recent past and do not grasp the future. They deserve the in-depth analysis they have garnered, but do not inform that much the conception of EU actorness articulated by its core institutions.

The corpus appears relevant to examine the EU actorness and more precisely, two specific dimensions of actorness: the ability to produce an identifiable and coherent discourse (cohesion), and to do so free from external pressure (autonomy). Covering a ten-year period allows us to measure stable elements as well as the dynamics of the European discourse. At first glance, we should expect a high level of stability, as an actor in international relations, especially when it comes to its relations with its neighbours, is supposed to follow a clear strategy. If a stable core of principles guides the actions and determines the objectives, this core should be revealed by our method.

\subsection{Text Statistics}

The chosen methodology for analysing the corpus follows directly the work on text analysis initiated by Lebart and Salem ${ }^{51}$, who built upon the factor analysis methods developed by Benzécri ${ }^{52}$. Lebart and Salem proposed a statistical approach to analyse the vocabulary from a text to complete the analysis and understanding of the content by limiting subjectivity of researchers when reading and explaining a given corpus of texts (literature, political speeches, etc.). The idea is to divide the text corpus into 'text units' of comparable size, which are subsequently considered to be statistical individuals whose variables are all the vocabulary used in the corpus ${ }^{53}$. This table, called the Aggregated Lexical Table, is subjected to factor anal-

\footnotetext{
${ }^{49}$ M. Smith, The Commission and External Relations, in G. Edwards and D. Spence (eds.), European Commission (London: Catermill 1997) pp. 264-303; Jones and Clark (note 39).

${ }^{50}$ Kelley, New Wine (note 3$)$.

${ }^{51}$ Lebart and Salem (note 17).

${ }^{52}$ J.P. Benzécri, L'analyse des données, Vol. 2 (Paris: Dunod 1976).

${ }^{53}$ Each box in the table contains 0 or 1 , indicating that a given word is absent from or present in the text unit. The table is described as 'hyper sparse' because it contains some $95 \%$ zeros.
} 
ysis and hierarchical classification to ?reveal a dimension of organisation in the text that 'memorises its conditions of production"54. In this study, the corpus was divided in nearly 1,700 segments of text, each one composed of 37 words (tool words like 'a', 'the', etc., are not taken into account for the partition). This partition is automatically made by the software used.

Quantitative methods are procedures which involve several choices depending on the hypothesis tested. The researcher defines at least three steps: the lemmatization process, the number of axes to be taken into account (factorial analysis) and the number of clusters kept (hierarchical classification). The lemmatisation aims at insuring that all different forms of a given object are considered as a single word. In our corpus, synonym terms like EU, European Union, the Union were replaced by the unique term EU. More generally, all institutions were replaced by their acronyms. Usual practices in textual analysis lead to keeping only the two first axes produced by the factorial analysis; a hierarchical procedure is then launched on the coordinates of statistical units (text segments) on these two axes. Finally, we decided to keep six classes (see part 2.1) of comparable size (that is featuring a comparable number of text segments).

This method is highly productive in social sciences ${ }^{55}$ because it detects 'lexical worlds ${ }^{56}$ that are hard to notice while reading a corpus. Two approaches were used to complete the analysis. First, we examined all seven documents as a single text in order to identify broad thematic areas and rationales that constitute the ENP; then we examined each document separately in order to reveal the thematic and geographical developments in the discourse during the studied decade. It allows for highlighting both the content of the ENP, especially regarding places, spaces and actors mentioned, and its stability over time. However, one drawback of the method must be reported: it is not possible to distinguish among meanings of polysemous words. For example, the word 'region' alternatively refers to an infra-national or to a supra-national space, and textual analysis does not account for any difference between the two scales. In this way, it should be borne in mind that statistical analysis does not replace a very close reading of the texts.

A major advantage of this method is to allow statistical measures regarding the lexical stability of the corpus, to examine both cohesion and autonomy dimensions of the ENP. The use of chi-squared tests is useful to determine when a given term is over-used or under-used in a specific document. Another interesting possibility is the examination of cooccurrences - terms often used together - which reveal thematic and spatial patterns in the corpus.

\footnotetext{
${ }^{54}$ M. Reinert, Les Mondes lexicaux des six numéros de la revue Le Surréalisme au Service de la Révolution", Mélusine XVI (1997) pp. 270-302.

${ }^{55} \mathrm{~F}$. Guérin-Pace, La statistique textuelle. Un outil exploratoire en sciences sociales, Population 52/4 (1997) pp. 865-887.

${ }^{56}$ Reinert (note 54$)$.
} 


\section{The EU and its Neighbours: A Regional Policy or a Collection of Bilateral Initiatives?}

Many options are available while carrying out a text analysis on a corpus and the results presented below focus on specific aspects regarding our hypothesis. In order to be as informative as possible, we first present and comment on three different outputs. We then propose our interpretation. In the first section, we focus on statistical counting and 'lexical worlds' revealed by textual analysis; the second section reflects on the geographical dimensions displayed on the ENP texts (states, regions and scales quoted); the third section highlights the dual nature of the neighbourhood (East and South); finally we interpret our results from the actorness perspective. In each section, if relevant, we differentiate the global approach (all texts considered as a whole) from the chronological approach (texts considered one after the other).

\subsection{Lexical Worlds of the ENP: Versatility or Stability?}

The length of the seven documents varies from 6,089 words (2006) to 12,125 (2004) (Table 2). The proportion of distinct words reflects the wealth of vocabulary: the higher it is, the more varied the vocabulary. In the corpus, the proportion of distinct words is relatively stable around $20 \%$. This indicates many repetitions and the use of similar terms, which is often the case for political and institutional discourses ${ }^{57}$. The slight variations between the documents (see Table 2) are explained by differences of length: a general rule in lexical analysis is that the longer the text, the higher the probability of getting similar words. The last row in the table gives the number of segments per text, each segment being considered as a statistical individual when the process of classification is launched. The partition obtained is exclusive and exhaustive: each text unit is part of a single class.

\begin{tabular}{lrrrrrrr}
\multicolumn{7}{c}{ TABLE 2: Description of ENP corpus } \\
\hline Dates & 2003 & 2004 & 2006 & 2007 & 2011 & 2012 & 2013 \\
Nb of occurrences & 7,442 & 12,125 & 6,089 & 4,853 & 9,666 & 10,151 & 10,465 \\
Nb of distinct words & 1,556 & 1,845 & 1,290 & 1,237 & 1,692 & 1,816 & 1,928 \\
\% of distinct words & 21 & 15 & 21 & 25 & 17 & 18 & 18 \\
Nb of text segments* & 294 & 353 & 171 & 134 & 265 & 277 & 292 \\
\hline
\end{tabular}

*A segment is the basic unit of analysis obtained by automatic partition of the text. Words counted here do not include tool words like a, the, on, etc.

While the process of segmentation is automatic, choosing the number of classes after the classification procedures remains the prerogative of the re-

\footnotetext{
${ }^{57}$ C. Muller, La statistique lexicale, Langue française 2 (1969) pp. 30-43.
} 
searcher. The choice to keep six classes, corresponding to six lexical worlds ${ }^{58}$, is justified by the clarity of the partition obtained from a lexical point of view. Table 3 presents the most representative terms (lexical forms) for each of these six classes and their frequency. The words are ranked according to their decreasing contribution to the formation of each class - for instance, health, environment and air do contribute significantly to the formation of Class 2, even if their raw occurrences are quite different (respectively 21, 57 and 11). The list of representative words for each class and their context of use gives meaning to each lexical world and suggests a heading that summarises the dominant features of this vocabulary (in capitals) - however these titles are our choices and are not results produced by a statistical method. It also must be noted that the size of the classes (the percentage indicates the proportion of text segments included in each class) does not demonstrate great discrepancies - as it ranks from 10 to $22 \%$.

Class 1 emerging from the analysis of the ENP corpus, refers to the economic dimension of the discourses and the policy's forms of action. It mainly involves the notions of 'partnership' between 'countries', 'reforms' and 'policy'. The vocabulary from Class 2 refers to development, particularly its environmental dimension plus social matters such as health, research and education. Class 3 is based on the regional dimension of the ENP. This geographical dimension concerns the outer edges of Europe and is expressed in the topic of enlargement to neighbouring countries and the nature of cooperation among partners. The words from Class 4 refer to European institutions by distinguishing them from Member States, international institutions and countries of the South in democratic transition. The lexical world of Class 5 denotes the forms of action of the neighbourhood policy and presents action plans, priorities, benchmarking, objectives, targets, agendas, etc. Class 6 comprises a set of words describing spatial entities, mainly country names, linked together by specific forms of action (Figure 1): negotiation, agreement, election, etc. The diagram (Figure 1) reveals co-occurrences structured around two groups of countries: one branch of the tree includes the Mediterranean States (with two exceptions: Israel and Palestine) and a separate branch consists of the Eastern neighbours. Words linking the two distinct neighbourhoods underline the institutional procedures implemented in the ENP (negotiation, agreement).

Among the six lexical dimensions (or classes) described above, some are more representative of some texts than others (as shown in the bottom row

\footnotetext{
${ }^{58}$ This analysis was done with Iramuteq freeware (Ratinaud) using the Alceste methodology developed by Reinert (note 54). Each text is divided into text segments that make up the rows of the Aggregated Lexical Table, where each column corresponds to the various words found in the corpus. The table, consisting of 0s (given word absent from segment) and $1 \mathrm{~s}$ (present), is subjected to divisive hierarchical clustering, which classifies units by the similarity or dissimilarity of their vocabulary. The specific vocabulary of each of these classes is a lexical world.
} 
Figure 1: Diagram of co-occurrences realised by authors with Iramuteq freeware (Ratinaut, 2013)

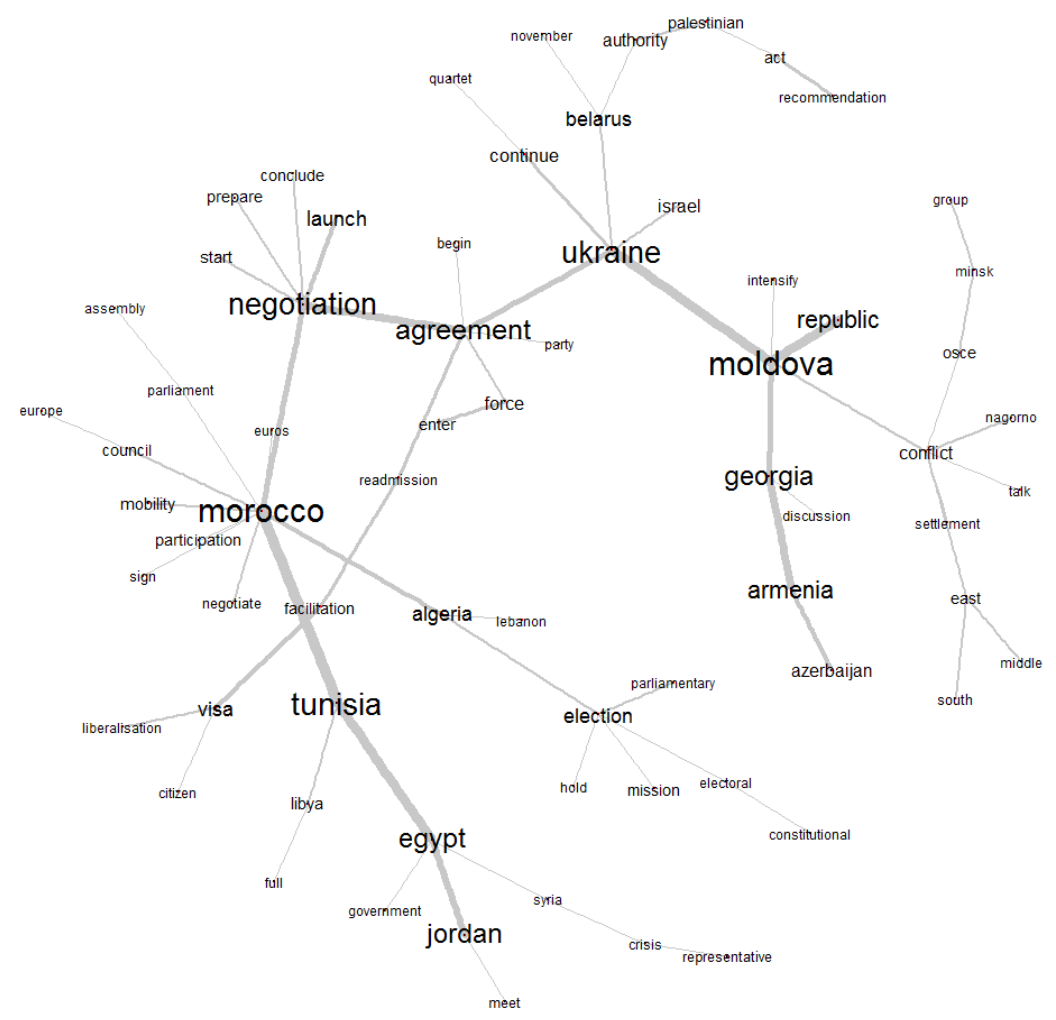

Source: ENP strategic communications, from 2003 to 2013. 
TABLE 3: Lexical worlds of ENP texts

\begin{tabular}{|c|c|c|c|c|c|c|c|c|c|c|c|}
\hline $\begin{array}{l}\text { Class } 1 \\
(22.5 \%)^{1} \\
\text { POLITCAL } \\
\text { ECONOMY }\end{array}$ & No. & $\begin{array}{l}\text { Class } 2 \\
(17.9 \%) \\
\text { ENVIRONMENT }\end{array}$ & No. & $\begin{array}{l}\text { Class } 3 \\
(20.9 \%) \\
\text { REGION }\end{array}$ & No. & $\begin{array}{l}\text { Class } 4 \\
(10 \%) \\
\text { NNSTITUTION } \\
\text { S }\end{array}$ & No. & $\begin{array}{l}\text { Class } 5 \\
(11.9 \%) \\
\text { ACTION }\end{array}$ & No. & $\begin{array}{l}\text { Class } 6 \\
(15.8 \%) \\
\text { STATES }\end{array}$ & No. \\
\hline $\begin{array}{l}\text { reform } \\
\text { partner } \\
\text { integration } \\
\text { financial } \\
\text { economic } \\
\text { aspiration } \\
\text { policy } \\
\text { ambition } \\
\text { incentive } \\
\text { progress } \\
\text { political } \\
\text { goal } \\
\text { commitment } \\
\text { mechanism } \\
\text { instrument } \\
\text { capacity } \\
\text { rule } \\
\text { flexibility } \\
\text { coherent } \\
\text { liberalisation } \\
\text { citizen } \\
\text { democratic }\end{array}$ & $\begin{array}{l}160 \\
372 \\
84 \\
80 \\
170 \\
9 \\
162 \\
15 \\
15 \\
93 \\
136 \\
17 \\
48 \\
10 \\
70 \\
46 \\
28 \\
8 \\
8 \\
26 \\
21 \\
42\end{array}$ & $\begin{array}{l}\text { health } \\
\text { environment } \\
\text { air } \\
\text { research } \\
\text { transport } \\
\text { safety } \\
\text { pollution } \\
\text { education } \\
\text { social } \\
\text { climate } \\
\text { human } \\
\text { law } \\
\text { innovation } \\
\text { improvement } \\
\text { energy } \\
\text { society } \\
\text { sustainable } \\
\text { right } \\
\text { employment } \\
\text { human } \\
\text { legislation } \\
\text { law }\end{array}$ & $\begin{array}{l}21 \\
57 \\
11 \\
21 \\
40 \\
17 \\
13 \\
14 \\
49 \\
20 \\
18 \\
25 \\
16 \\
15 \\
57 \\
74 \\
37 \\
17 \\
14 \\
18 \\
15 \\
25\end{array}$ & $\begin{array}{l}\text { Regional } \\
\text { sea } \\
\text { cooperation } \\
\text { border } \\
\text { black } \\
\text { Mediterranean } \\
\text { bilateral } \\
\text { southern } \\
\text { neighbourhood } \\
\text { enlargement } \\
\text { eastern } \\
\text { partnership } \\
\text { multilateral } \\
\text { stability } \\
\text { prosperity } \\
\text { Turkey } \\
\text { neighbour } \\
\text { initiative } \\
\text { ENP } \\
\text { Dialogue }\end{array}$ & $\begin{array}{l}150 \\
25 \\
244 \\
82 \\
17 \\
105 \\
46 \\
70 \\
128 \\
12 \\
73 \\
135 \\
13 \\
24 \\
14 \\
12 \\
125 \\
41 \\
205 \\
103\end{array}$ & $\begin{array}{l}\text { State } \\
\text { member } \\
\text { international } \\
\text { transition } \\
\text { coordination } \\
\text { conflict } \\
\text { organisation } \\
\text { institution } \\
\text { democratic } \\
\text { region } \\
\text { crisis } \\
\text { transformation } \\
\text { resolution } \\
\text { actor } \\
\text { role } \\
\text { democracy } \\
\text { involvement } \\
\text { representative } \\
\text { effort } \\
\text { active } \\
\text { support }\end{array}$ & $\begin{array}{l}80 \\
67 \\
53 \\
22 \\
13 \\
51 \\
37 \\
37 \\
42 \\
65 \\
23 \\
11 \\
17 \\
17 \\
20 \\
32 \\
16 \\
25 \\
78 \\
13 \\
191\end{array}$ & $\begin{array}{l}\text { plan } \\
\text { action } \\
\text { priority } \\
\text { report } \\
\text { benchmark } \\
\text { progress } \\
\text { monitor } \\
\text { assessment } \\
\text { agenda } \\
\text { commitment } \\
\text { communicatio } \\
\text { n } \\
\text { identify } \\
\text { implement } \\
\text { value } \\
\text { agreement } \\
\text { focus } \\
\text { issue } \\
\text { country } \\
\text { strategic } \\
\text { initiative }\end{array}$ & $\begin{array}{l}120 \\
154 \\
67 \\
20 \\
13 \\
93 \\
25 \\
16 \\
25 \\
48 \\
41 \\
34 \\
51 \\
41 \\
102 \\
33 \\
80 \\
363 \\
18 \\
41\end{array}$ & $\begin{array}{l}\text { Morocco } \\
\text { Tunisia } \\
\text { Moldova } \\
\text { Jordan } \\
\text { Egypt } \\
\text { Georgia } \\
\text { Armenia } \\
\text { republic } \\
\text { Ukraine } \\
\text { negotiation } \\
\text { Algeria } \\
\text { Azerbaijan } \\
\text { Israel } \\
\text { election } \\
\text { Palestinian } \\
\text { Libya } \\
\text { Belarus } \\
\text { OSCE } \\
\text { visa } \\
\text { mission } \\
\text { force } \\
\text { authority } \\
\text { agreement }\end{array}$ & $\begin{array}{l}45 \\
41 \\
46 \\
33 \\
34 \\
34 \\
28 \\
28 \\
40 \\
39 \\
19 \\
16 \\
15 \\
19 \\
12 \\
13 \\
19 \\
11 \\
20 \\
12 \\
16 \\
16 \\
35\end{array}$ \\
\hline $\begin{array}{l}2012 \\
2013\end{array}$ & & $\begin{array}{l}2006 \\
2011\end{array}$ & & $\begin{array}{l}2003 \\
2004\end{array}$ & & $\begin{array}{l}2003 \\
2006 \\
\end{array}$ & & $\begin{array}{l}2004 \\
2006\end{array}$ & & $\begin{array}{l}2011 \\
2012\end{array}$ & \\
\hline
\end{tabular}

1. Proportion of all text segments that belong to a given class.

Source: ENP strategic communications, from 2003 to 2013. Computations and tabulations made by authors with Iramuteq freeware (Ratinaut, 2013).

of Table 2) and correspond to a particular period. The vocabulary referring to the economic dimension of discourses and associated forms of action is more representative of recent years. The lexis in Class 2 (development, environment, health, research, education) is more present in 2006 and in 2011. The regional and institutional dimensions are more representative of the period during which the neighbourhood policy is implemented (2004). The economic and state dimensions connect more with recent years, no doubt in relation to the economic crisis and upheavals around the Arab world.

A number of lessons may be drawn from the identification of these lexical worlds. We see a clear dominance of the economic component in the discourse (Class 1): it is most present in the texts (highest proportion of text segments); Class 1 is also more homogeneous than Class 2, which varies in combining aspects of health, environment, research, transport, etc. Economic catch-up of the neighbouring states is thus the main challenge for the ENP, particularly in the recent period, and appears to displace the environmental and social issues that regularly recur (2006 and 2011). Furthermore, the proactive aspect emphasised by the EU in its texts can be clearly seen in the specific vocabulary of Class 5 (action verbs and terms indicating the proactive nature of the ENP).

The text analysis of ENP documents can be refined along more specific lines by introducing the time dimension, which fine-tunes these remarks. The 
Chi-squared test enables figuring out whether a determined word is underor over-represented in a specific document. Some themes (democracy, democratic, partnership, dialogue) are under-represented at the beginning of the period and are clearly over-represented at the end. Some words (border, cooperation,union) are over-represented at the beginning of the period and under-represented at the end. The $\chi^{2}$ test confirms that the European discourse is, to a certain extent, versatile, but certain evolutions mentioned here cannot be easily explained. For instance, the emergence of democracy and democratic at the end of the period is caused by the Arab revolutions. But the diminishing appearance of 'order' is trickier. No word is over-represented in three texts or more. In most cases, words are over-represented in only one document and only very few themes are over-represented in two documents (border, commission, cooperation, democracy, democratic, election, enhance, sea, transition, union). By contrast, some terms are under-represented three times or more: cooperation, plan, partnership, action, will. Nevertheless, a clear majority of the words are never or rarely over- or under-represented. They constitute a sort of base-line of the corpus. They include: agreement, agriculture, aid, assist, assistance, bilateral, development, differentiate, differentiation, economy, education, environment, region, security, unemployment... They establish a sense of stability of the European discourse over the whole period.

\subsection{Thinking That is More State-Centred Than Regional}

After the lexical worlds, we examined scales used to describe the neighbourhood policy. Within certain institutions such as the UN, the European Union often presents a vision of the world based on multilateralism and the allegedly crucial importance of supranational constructions ${ }^{59}$. Do we see this aspiration reflected in the corpus? To examine this, we first built a list of relevant items related to this topic (e.g., world, region, state, country, local); we subsequently checked in the texts that we did not forget any term. Then we examine their frequency and their statistical significance.

In the list of scalar terms, there are few over- or under-represented words in the corpus, only seven out of a total of eighty-four words (see Table 4). This reveals a great stability in discourse denoting the scale of action. The predominant scale in all documents is the country, meaning partner countries. This is the ENP spatial brick of reference, and it is not surprising, as the logic of the ENP is mainly bilateral. The term region, over-represented only in the 2014 document, comes far behind with less than half the occurrences. The word 'state' comes third and is almost always used to denote Member States as opposed to neighbouring countries. The local or global

\footnotetext{
${ }^{59}$ L. Beauguitte, L'Assemblée générale de 1985 à nos jours. Essai de géographie politique quantitative, $\mathrm{PhD}$ dissertation, Paris 7, 2011.
} 
TABle 4: Occurrences of Scalar Terms in the Seven Communications

\begin{tabular}{|l|c|c|c|c|c|c|r|r|}
\hline Form & $\mathbf{2 0 0 3}$ & $\mathbf{2 0 0 4}$ & $\mathbf{2 0 0 6}$ & $\mathbf{2 0 0 7}$ & $\mathbf{2 0 1 1}$ & $\mathbf{2 0 1 2}$ & $\mathbf{2 0 1 3}$ & Total \\
\hline country & 81 & $\mathbf{1 5 2}$ & 51 & 50 & 84 & 86 & 89 & 593 \\
\hline regional & 28 & $\mathbf{6 2}$ & 28 & 15 & 32 & 24 & 20 & 209 \\
\hline State & 12 & 22 & 17 & 16 & 15 & 16 & 23 & 121 \\
\hline region & 10 & 16 & 10 & 8 & 25 & 14 & 18 & 101 \\
\hline international & 7 & 14 & 4 & 4 & 18 & 18 & 17 & 82 \\
\hline bilateral & 4 & 15 & 7 & 7 & 14 & 2 & 10 & 59 \\
\hline national & $\mathbf{1 1}$ & 9 & 5 & 2 & 4 & 1 & 9 & 41 \\
\hline local & 3 & 10 & 4 & 5 & 1 & 5 & 4 & 32 \\
\hline multilateral & 1 & 2 & $\mathbf{8}$ & 0 & 3 & 4 & 3 & 21 \\
\hline world & 1 & 5 & 1 & 0 & 1 & 2 & 3 & 13 \\
\hline global & 1 & 1 & 1 & 1 & 4 & 1 & 3 & 12 \\
\hline universal & 0 & 1 & 0 & 0 & 4 & 3 & 3 & 11 \\
\hline
\end{tabular}

Only terms used at least 10 times in the whole corpus are included. Bold means that term is over-represented at that date, and italic that it is underrepresented $\left.\left(\chi^{2} \geq \mid 2\right]\right)$.

Source: ENP strategic communications, from 2003 to 2013. Computations and tabulations made by authors with Iramuteq freeware (Ratinaut, 2013).

scales are not very present in the whole corpus, which can easily be explained once again by the bilateral nature of ENP.

This main finding is worth underlining as it shows how malleable European discourse is on the international stage according to the issues involved. Although the EU often adopts a global discourse about universal values ${ }^{60}$, in the ENP framework texts it makes the national scale first and coherent regional groupings such as the EU facing the eligible ENP countries second.

A slight resurgence of 'multilateralism' occurred in 2006, when the term is used to promote 'efforts', 'agreements', and 'dialogue', or to solve 'conflicts'. But references to multilateralism are to be found again only three times in the 2103 document and denote 'progress', 'reflect on how to have a more multilateral policy approach' and to express a 'need to fully implement the multilateral environmental agreements'. This shows that the ENP regularly takes the form of a bilateral relationship between a clearly identified state and the EU as a whole. This finding is confirmed in the examination of the actors and explicitly spaces named in ENP texts.

\subsection{Two Different Neighbourhoods and Their Respective Trends}

The European Neighbourhood Policy actually deals with two distinct neighbourhoods: a Southern and an Eastern neighbourhood. Regardless of the

\footnotetext{
${ }^{60}$ L. Beauguitte and Y. Richard, Analyse géographique d'un discours politique. L'exemple des brochures L'Union européenne dans le monde, Belgeo 4 (2013), available at http://belgeo.revues.org/8604.
} 
used method (ranking, co-occurrence, lexical worlds) and the examined period, the Eastern and Southern neighbourhoods are treated separately. This is not surprising, since their economic, demographic, social and environmental issues are different.

Although the names of States are the most frequent in the vocabulary relating to the scale of intervention, the regional dimension is also often mentioned (Tables 5 and 6): Eastern Europe and the Mediterranean or Southern region. Documents often highlight general issues, then divide the neighbourhood into two subsets and present the specific issues and priorities of each subset. Finally, the documents present in detail all actors involved (i.e., states) and the practical modalities of the EU cooperation.

TABle 5: Occurrences of Places and Spaces Related to the Eastern Neighbourhood

\begin{tabular}{|l|c|c|c|c|c|c|r|r|}
\hline Form & $\mathbf{2 0 0 3}$ & $\mathbf{2 0 0 4}$ & $\mathbf{2 0 0 6}$ & $\mathbf{2 0 0 7}$ & $\mathbf{2 0 1 1}$ & $\mathbf{2 0 1 2}$ & $\mathbf{2 0 1 3}$ & Total \\
\hline Eastern & 7 & 7 & 4 & 0 & $\mathbf{4 5}$ & $\mathbf{4 2}$ & 24 & 129 \\
\hline Ukraine & 11 & 7 & 4 & 12 & 8 & 13 & 19 & 74 \\
\hline Moldova & 12 & 5 & 5 & 5 & 10 & 15 & 19 & 71 \\
\hline Russia & $\mathbf{4 0}$ & 17 & 3 & 0 & 1 & 1 & 1 & 63 \\
\hline Belarus & $\mathbf{1 5}$ & $\mathbf{2 2}$ & 0 & 1 & 3 & 10 & 8 & 59 \\
\hline Georgia & 0 & 4 & 0 & 5 & 3 & 10 & $\mathbf{2 1}$ & 43 \\
\hline East & 0 & 7 & 4 & 6 & 5 & 5 & 10 & 37 \\
\hline Armenia & 0 & 4 & 0 & 2 & 1 & 12 & 13 & 32 \\
\hline Azerbaijan & 0 & 4 & 0 & 2 & 0 & 8 & 11 & 25 \\
\hline Caucasus & 0 & 6 & 5 & 0 & 2 & 1 & 2 & 16 \\
\hline
\end{tabular}

Only terms used at least 10 times in the whole corpus are included. Bold means that term is over-represented at that date, and italic that it is underrepresented $\left.\left(\chi^{2} \geq \mid 2\right]\right)$.

Source: ENP strategic communications, from 2003 to 2013. Computations and tabulations made by authors with Iramuteq freeware (Ratinaut, 2013).

It is however noteworthy, and we deal with this later, that regional actors from the East and South are not considered valid interlocutors, to the point that they are not at all mentioned in the corpus: the rationale is that the negotiations involve the EU and solely the states on a bilateral basis. This bilateral approach might explain the absence of other regional institutions, but the invisibility of regional powers such as Turkey or Russia is more difficult to justify. Moreover other political and/or world powers are also not taken into account, there is no occurrence of USA, China or Japan, for example.

With regard to the places and actors mentioned, two major trends over time can be distinguished: first, the impact of Arab Spring is visible, with an increase in the number of references to all the states in the Southern neighbourhood, with the notable exception of Libya (Table 6); second, a 
TABle 6: Occurrences of Places and Spaces Related to the Southern Neighbourhood

\begin{tabular}{|l|c|c|c|c|c|c|r|r|}
\hline Form & $\mathbf{2 0 0 3}$ & $\mathbf{2 0 0 4}$ & $\mathbf{2 0 0 6}$ & $\mathbf{2 0 0 7}$ & $\mathbf{2 0 1 1}$ & $\mathbf{2 0 1 2}$ & $\mathbf{2 0 1 3}$ & Total \\
\hline Mediterranean & $\mathbf{3 7}$ & 38 & 14 & 11 & 33 & 26 & 22 & 181 \\
\hline Southern & 12 & 8 & 7 & 2 & 18 & $\mathbf{3 4}$ & 23 & 104 \\
\hline Tunisia & 2 & 2 & 1 & 0 & 6 & $\mathbf{2 4}$ & $\mathbf{2 0}$ & 55 \\
\hline Morocco & 4 & 2 & 2 & 5 & 4 & $\mathbf{2 0}$ & 14 & 51 \\
\hline Egypt & 2 & 4 & 1 & 1 & 6 & 13 & $\mathbf{1 9}$ & 46 \\
\hline Jordan & 0 & 1 & 1 & 2 & 1 & $\mathbf{1 6}$ & $\mathbf{1 5}$ & 36 \\
\hline Libya & 7 & 11 & 0 & 1 & 2 & 3 & 9 & 33 \\
\hline South & 0 & 6 & 2 & 3 & 8 & 5 & 7 & 31 \\
\hline Algeria & 4 & 2 & 0 & 2 & 0 & 7 & 8 & 23 \\
\hline Israel & 3 & 2 & 1 & 5 & 0 & 2 & 5 & 18 \\
\hline Palestinian & 1 & 2 & 3 & 0 & 2 & 2 & 5 & 15 \\
\hline Syria & 2 & 1 & 0 & 1 & 1 & 4 & 5 & 14 \\
\hline Turkey & 3 & 2 & 2 & 1 & 3 & 1 & 1 & 13 \\
\hline Lebanon & 2 & 2 & 1 & 0 & 0 & 0 & 5 & 10 \\
\hline Maghreb & 0 & 3 & 0 & 1 & 1 & 3 & 2 & 10 \\
\hline
\end{tabular}

Only terms used at least 10 times in the whole corpus are included. Bold means that term is over-represented at that date, and italic that it is underrepresented $\left.\left(\chi^{2} \geq \mid 2\right]\right)$.

Source: ENP strategic communications, from 2003 to 2013. Computations and tabulations made by authors with Iramuteq freeware (Ratinaut, 2013).

considerable fluctuation of references to the East is observed, with the rise of the Georgia-Ukraine-Moldova trio and the disappearance of Russia which cannot be easily explained. One possible explanation would be that the first text needed to be very precise regarding the mentioned spaces and actors, in order to clearly define the geographical scope of the neighbourhood policy. As the process went on, it became less necessary to present the ENP with such precision (i.e., the targeted countries listed one by one), explaining for example why the broad and inclusive word East became the most frequent term in 2012 and 2013 (Table 5). On the other hand, when a specific event occurs in a given country, it becomes highly quoted in the subsequently issued ENP text (see for example Tunisia after 2011 or Georgia after 2008). The shift in the document regarding the South and the removal of Russia is illustrated in th maps (Figure 2) showing the two extremities of the period under study (2003 and 2013). However, occurrences in countries do not vary greatly, indicating an overall stability, which barely affects the overall strategy with occasional fluctuations.

Examining which and how places and actors are mentioned confirms what is suggested by the structure of the ENP texts: a closer analysis shows not one European neighbourhood policy but rather differentiated policies towards actors considered separately (see also the predominance of the state 
Figure 2: Occurrences of State names in ENP texts in 2003 and 2013

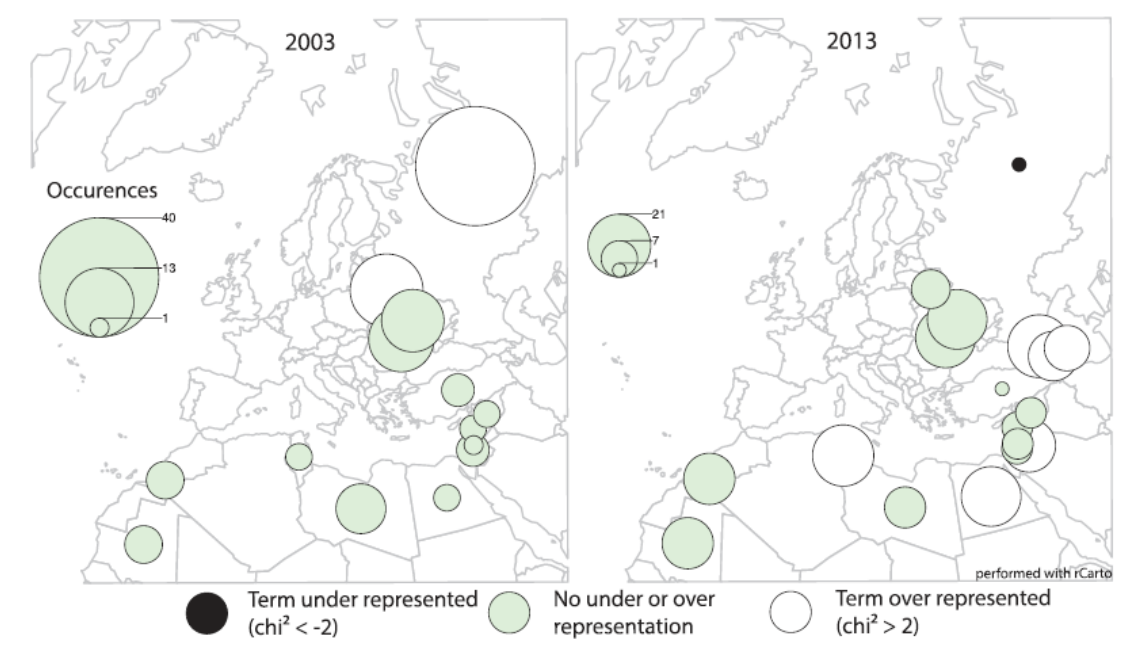

Source: ENP strategic communications, from 2003 to 2013.

scale mentioned above) and combined by convenience into two rather illdefined geographical groups: the Eastern and Southern neighbourhoods. The fluctuations observed are larger for the frequency of mentions per country than for the scales of intervention, revealing the stability in the EU principles and a capacity to adapt its discourse to ongoing events. Finally, the ENP documents tend to react to these events, and do not take the risk of predicting developments: the European neighbourhood discourse is therefore more determined - mainly by external developments - than determining.

\section{European Discourse, Textual Analysis and Ac- torness}

Textual analysis allows reaching two complementary objectives regarding the actorness of the EU: to confront previous researches based on other approaches and to provide new insights regarding stability of the ENP discourse. However, some limitations to our approach have to be kept in mind. While textual analysis seems an interesting option, its aim is to complement qualitative studies, rather than to replace them.

\subsection{Textual Analysis as a Testing Tool}

Some results presented above do confirm that the ENP appears as a primarily bilateral process allowing the EU to organise its neighbourhood in 
two distinct spheres, East and South. The overall preference for a bilateral approach can be easily explained: it is much easier for the EU to move ahead on a bilateral basis than to carry out negotiations at the regional level. The bilateral approach is based on the idea that the EU will help and fund most the countries that implement the most the reforms it requires. Actually, this is somehow problematic. Pushing some individual countries to implement various reforms as the ENP does, has two possible consequences. On the one hand, it can foster regional integration because the more advanced the Europeanisation process, the more neighbouring countries can be seen as best-practice examples. But, on the other hand, the bilateral approach can accentuate disparities between participating countries, making it more and more difficult to implement common initiatives, eventually paving the way to a fragmentation of the neighbouring 'region'.

Most of the time, two neighbourhoods are distinguished in the framework documents. It shows the efforts made by the EU to push forward the idea that the eastern and the southern neighbours are different. It can be interpreted as a discursive practice of EU identity formation in which the South represents the oppositional 'other', whereas the East has roots in European history and might well 'return to Europe' as other former Eastern European countries and Soviet Republics have done with the 2004 and 2007 enlargements. Besides, the East/South distinction may be interpreted as an outcome of the balance of power between EU Member states which pay more attention to North Africa and the Mediterranean (France, Italy, Spain) and those supporting the Eastern countries (Germany, Poland, the Baltic states, Sweden). From this point of view, the textual analysis reveals a strong coherence of the European discourse over the whole period. Graphs of cooccurrence show that the neighbouring countries are most of the time divided into two categories when they are individually mentioned.

Last, from a thematic perspective, aspects related to economy and trade are clearly predominant. They are followed by the lexical worlds of regional integration. All things considered, the ENP discourse is cohesive.

\subsection{Textual Analysis and Unexpected Outcome}

Getting confirmation of results obtained with different methods is a first and reassuring step. But textual analysis also provides unexpected and interesting outputs, especially from a time perspective. Measuring occurrences of words allowed us to highlight also the relative spatial versatility of the ENP and some remarkable absences (regional powers and non-EU regional bodies). The ENP texts preferentially mention the eligible countries and this is perfectly logical and expected, but the increasing neglect over time of regional powers Russia and Turkey (mentioned less than ten times in ten years) is more surprising (see Table 4). Implementing a neighbourhood policy without taking account of the regional interests and strategies of these 
two actors is highly questionable.

Russia's disappearance after the document issued in 2003 and Turkey's virtual absence may be interpreted in various ways. One interpretation is that the EU deliberately intends not to take into account the proximity of these two countries while implementing policy action in its neighbourhood. Another interpretation favours an inadvertent omission as the EU has a specific policy towards Russia and Turkey is a candidate member state negotiating accession to the EU. In both cases, it is surely an odd perspective concerning the social, political, economic and ultimately territorial expansion or retraction of its regional bounds. Russia is not eligible for the neighbourhood policy, but plays a considerable role in developments in the countries of the Eastern neighbourhood, a role that was clearly highlighted in the first text of the ENP. Its regional influence in the Caucasus, Black Sea, Eastern Europe and the Baltic is such that it seems illusory to develop initiatives in a whole range of fields without thinking to strengthen cooperation with Russia.

The framework documents entirely ignore the existing regional bodies East and South. There is not even a slight and rapid allusion, until the 2013 communication. This outspoken preference for bilateral agreements between the EU and eligible states taken separately from their neighbours can only feed the suspicions of imperialism regarding this policy because of the flagrant asymmetry of power relations. The neglect of regional agreements in the neighbourhood (such as the Belarus-Kazakhstan-Russia customs union, foreshadowing a future Eurasian Union) can be found in other European Union discourses ${ }^{61}$. The exceptional status generally accorded to the European integration process, considered as a form of self-congratulation frequent among EU stakeholders and academics, may lead them to dismiss other attempts at region building. Ignoring neighbouring regional bodies might however nullify the effectiveness of the neighbourhood policy, for example regarding free-trade agreements: Belarus could engage with the EU neighbourhood policy and the Belarus-Kazakhstan-Russia customs union. This state cannot now sign any trade agreement with the EU because it has already devolved part of its sovereignty in this area to the Customs Union Treaty which unites Kazakhstan, Russia and Belarus; it would only be possible if Russia and Kazakhstan sign a similar agreement and apply the same standards. The same goes for Armenia, which has decided to join the same customs union. At best, this neglect makes the ENP ineffective; at worst, it may provoke negative reactions from the potential partners and from Russia.

A corollary of the bilateral approach is a sharp differentiation in the treatment of potential partners in the ENP. In theory, all neighbours are

\footnotetext{
${ }^{61}$ See for example the progress reports of the ENP, available on the website www.europa.eu, http://eeas.europa.eu/enp/documents/progressreports/index_en.htm or the reference documents of the Eastern partnership (http://eeas.europa.eu/eastern/docs/index_en.htm).
} 
equal and the EU should grant them equal attention. Nevertheless, there are wide differences between neighbouring countries. For example, Algeria is barely mentioned. This virtual omission may be due to the poor relations between the EU and Algeria. Algeria is a major energy supplier for the EU, which does not want to be too dependent on Russia for its gas, but the European institutions often criticise Algeria in the economic and political fields. Furthermore, formal relations with Algeria have not advanced since the entry into force of the association agreement in 2005, while other countries signed strengthened association agreements. On the contrary, Ukraine and Moldova are often mentioned throughout the corpus and come on top of the rankings in each document taken separately. It can be assumed that the EU shows more attention and interest to certain countries depending on the efforts they are prepared to make to come closer to the EU. This adheres to the principle of differentiation: the ENP varies according to the desire and ability of the eligible countries to advance their association with the EU.

\subsection{Some limits of the exercice}

If textual analysis provides an interesting tool for political geography, it does not attempt to replace more traditional approaches to discourse for several reasons. First, it neglects many aspects of text structure (outline, topics emphasised with titles or subtitles, order of presentation of spaces and topics, etc.). While this can be of great interest and could give more substance to the analysis, as of yet the logics of argumentation mobilised by the authors is not taken into consideration. Second, polysemy is a challenge, and the use of some words must be carefully examined before interpreting results and supposes pre-treatment of the corpus before launching the analysis. For example, we first intended to examine verbs used in the corpus to examine the expected pro-active nature of EU actions. We had to give up this exploration, as it was not possible to distinguish between nominal and verbal forms without manual action ('a need for reform' versus 'we need to reform' for example). The purpose of the method is to measure various characteristics of the texts (length, occurrences and co-occurrences, etc.) with as few interventions as possible on the initial corpus, each human choice involving some subjectivity. Another limitation which makes the linear reading and analysis of the corpus complementary is the underestimation of some actors with our method. The EU is the most frequently quoted actor in our corpus, which is perfectly expected for this corpus, but its importance is still underestimated because pronominal forms ('It will...', 'We will...') are not counted as occurrences of 'The EU will...'). 


\section{Conlusion}

European actorness is a research topic dominated by specialists in international relations who have produced a large number of valuable studies. This article is intended to show that geography can make a significant contribution to the study of the European Union because it is able to propose a spatialised approach to certain criteria for actorness. The focus here has been on coherence or cohesion and opportunity. The results obtained allow us to better grasp how the EU (European Commission and EEAS) considers its neighbourhood. First, and not surprisingly, the European discourse suggests that the relationship with the neighbourhood is seen in a Eurocentric and bilateral way. Second, the Eastern and Southern neighbourhoods are always distinguished in the texts. Third, we also note that regional powers (Turkey and Russia) and regional organisations (particularly the regional associations from the Eastern neighbourhood, only fleetingly mentioned in the final text) are absent or virtually absent from the corpus. Last, the European discourse about the neighbourhood looks more determined than determining. It is characterised by an apparent stability (especially when it comes to the scales of intervention), but the textual analysis shows dramatic variations and the strategic texts of the ENP are versatile when it comes to the places and actors explicitly mentioned. In these matters the European discourse is very much influenced by the evolutions of the political regional context (there is an Arab spring effect and a South-to-East switch with the events in Ukraine), which is problematic in terms of actorness. On the one hand, of course, an actor cannot ignore the context. On the other hand, a versatile discourse is blurred and less intelligible to potential partners.

Scholars in International Relations and critical geopolitics seldom use the statistical approach in their analysis of policies such as the ENP. The text analysis of the framework documents of the European Neighbourhood Policy usefully complements the approaches proposed by critical geopolitics. The analysis of terms frequency and co-occurrence and the classification procedure, the detailed study of specific topics (scales and spaces) helped us to confirm the results of previous qualitative studies. A next step would be to combine both approaches on a selected corpus to elaborate a mixed method (qualitative and quantitative) of analysis. Finally, it is worth bearing in mind that the quantitative methods do not replace thematic and regional expertise which remains needed in order to interpret properly the results, and are useless if they are carried out without any conceptual framework and hypothesis.

In this study, EU actorness is addressed through the analysis of a corpus exclusively composed by official documents written and released by the European Commission and the EEAS (seven strategic Communications). These documents are the result of a collective work done by the European Commission (later by the European External Action Service). They represent 
the point of view of the European Union as a whole, neglecting internal divisions between Member States. This is certainly one of the main limits of our approach, even if the ENP is not the most confrontational issue in the day-to-day life of the EU. Internal divisions would have been more visible if we had analysed more controversial topics such as defence and military affairs. In this field, the actorness of the European institutions is obviously more fragile because of strong internal divisions between the Member States. Moreover, it would be instructive to consider how a first-ranked actor like NATO considers the EU. A textual analysis of various official documents (for instance the annual reports and the strategic concept of 2010) could show to which extent the EU is considered as an actor or not in international security affairs. Another step forward would be to analyse a larger and less homogeneous corpus to investigate the relevance of the approach: including documents produced by different actors, EU institutions, but also Member States, partner countries and other regional organisations and to consider whether other characteristics of the ENP discourse or alternative ENP discourses would be distinguished and how they are related to each other. 